\title{
P. R. and Democracy
}

\section{By F. A. Hermens}

WHEN, at a party in New York, the question was asked: "What does the abbreviation 'P. R.' stand for?" a lady - a college graduate, from just across the Hudson River in New Jersey-answered: "A new alphabetic agency." Harold Phelps Stokes, writing for the New York Times Book Review, thought that the two letters came close to expressing "a term of endearment." 1 The Baltimore Sun wrote in the same vein by terming it "the darling of the pure idealists of democracy." 2 The New York Sun was more explicit: "It is the pari-mutuel of politics, a bingo of the ballots, manna for the minorities." 3 And, to turn to a more serious aspect of the matter, a prominent American political scientist, in a letter to the present writer, called P. R. a "substitute religion," and just one of the manifestations of that "mechanized dogmatism" for which he-as any true scientistcared but little.

Of these explanations of P. R. only the one by the lady from New Jersey is wrong, and, as will be explained below, all the others are right. P. R. stands, of course, for a system of voting. Of this system it is as characteristic that its advocates-rather scornfully-reject the one that we are now using, as that it has certain-rather balefulfeatures of its own. It will be useful, however, to analyze the deep meaning and true significance of our current system of voting before we pass on to an investigation of the promises, and the performance, of its rival.

The majority system of voting is as old as are parliamentary bodies. It is firmly rooted in Anglo-Saxon tradition; it was always used for the election of the English House of Commons, and was taken over by the American colonies as soon as they established organs of selfgovernment. Its mechanism is as simple as its results are beneficial.

1 "Speaking of P. R.," September 28, 1941, p. 18.

2 "Worked in Reverse," editorial, November 3, 1936.

3 George Ritchie, "Book of the Day," October 28, 1941, p. 34. 
For example, for the purpose of electing the members of the House of Representatives we divide the country-apart from certain cases of elections in a state at large-into districts. One candidate is elected from each district. Victory goes to the one who polls the largest number of votes, whether he has secured more than 50 per cent of them or not. We call this the plurality system. No one denies that under this system the voter knows for whom he votes, and that a few hours after the closing of the polls a clear decision has been reached and everyone knows where he stands.

More than simplicity of method and the speedy manifestation of the popular will are involved, however. To repeat what has been said before: The process used in our system of voting is as important as the result achieved. That process is one of persuasion, and, as a result, we may say that government by majority is government by persuasion. With exceptions ${ }^{4}$ which only go to confirm the rule, it is true that the American voter must be persuaded, and cannot be coerced. Whosoever has gathered the greatest number of voters has been more successful in this process of persuasion than any rival. He has not only worked for himself, but he has also made a mighty contribution to the cementing of national unity. As the political scientist would put it: He has performed an act of integration.

It is evident that this simple consideration disposes of "the venerable bugbear, the tyranny of majorities." Injustice is done neither to the one large nor to the small minorities. In countries like the United States and England the plurality system has demonstrated a tendency to create a system of two parties, and in others the majority system has led to the development of two rivalling blocs of parties, which in most respects can serve the same purpose as a two-party system. It is obvious that neither in English nor in American political history the minority party has been eradicated and its wishes disregarded. In fact the decisive political power rests with neither major party; it lies in the hands of the independent voter, who can turn to either side, and who for that reason forces the major parties to have tenets so similar to

4 They have been discussed in my article, "Exit the Boss," Revien of Politics, October 1940.

5 J. P. Quincy, The Protection of Majorities, Boston 1876, p. 6. 
one another that they have been accused of being as much alike as "tweedledum and tweedledee." This, of course, goes to show that actual political differences are never as great as they have appeared to academic observers, and from the point of view of national unity we can only say that they should not be. There must be a body of principles to which all influential leaders subscribe, and under a majority system of voting they cannot succeed unless they do so. $\beta$

Religious, racial, social, minorities, no matter how small, will be protected as much as the one great political minority. It takes members of many a minority to make up a majority, and few candidates will want to risk defeat by antagonizing any group of potential supporters. We must bear in mind that any minority group of a non-radical type will have friends among the members of the majority group. These fair-minded people will consider it an infringement of their own rights if the rights of other people are disregarded. Also, as Madison ${ }^{\text {? }}$ advised us such a long time ago, if there should develop an intolerant majority in some section of a large country like the United States, it will tend to be offset by the views and actions of the people in other parts of the country.

History supports what theoretical analysis demonstrates. Take the case of England, where legally the majority of the day can, as long as it controls parliament, do anything it chooses to do. As Blackstone put it: "The power and jurisdiction of Parliament, says Sir Edward Coke, is so transcendent and absolute, that it can not be confined, either for causes or persons, within any bounds. . . . It can, in short, do everything that is not naturally impossible, and therefore some have not scrupled to call its power, by a figure rather too bold, the omnipotence of Parliament." 8 Yet, any detailed investigation would show that in England, in spite of the absence of a written bill of rights, the natural rights of the people are at least as well safeguarded as they are in any other country, and that the House of Commons is the

6 For some details see F. A. Hermens, "The 1938 Elections and the American Party System;" Revien of Politics. April 1939.

7 In No. $X$ of the Federalist papers.

8 Commentaries on the Laws of England, I, 160-1. 
most jealous guardian of these rights. ${ }^{9}$ Also, it is good to remember that such an important step as the emancipation of the Catholics was taken by a parliament in which there were no Catholics at all-in other words, the politician's regard for those fair-minded Protestants who rejected religious discrimination was enough to make it necessary to restore the rights of a minority group which had no legal right to defend itself: Or take the case of the United States. Colonial laws at first excluded religious minorities from the suffrage, but after the revolution it was not long before the religious majority everywhere gave up its monopoly of power. Nor has this process of granting increased toleration slowed down in subsequent generations. When Tocqueville came to the United States and watched the results of the Jacksonian revolution, he was still fearful of a "tyranny of the majority."10 Lord Bryce ${ }^{\mathbf{1 1}}$ took up the same matter two generations later. He could not but realize that the position of minority groups had improved since the time of Tocqueville, and he rightly concluded that if the continued application of majority rule led to a betterment in the condition of minorities, it could not in itself have any oppressive implications. In fact, we can indeed only conclude this brief analysis of majority rule by quoting Thomas Woodlock, who had this to say: "Democracy is the protection of minorities by the rule of the majority." 12

These are the basic elements in the system of voting which the American Republic has applied since its establishment. The Founding Fathers used it, and handed it on to their descendants. It can hardly be claimed that this was an accident; the same trend of thought which Madison employs to prove that rule by intolerant factions will be the less likely the larger the district in which a vote is taken, will lead to the conclusion that majorities are, generally speaking, less inclined to

9 See W. J. Jennings, Parliament, New York, 1940, pp. 95-96, who discusses a case of the alleged application of "third degree" methods. Says Jennings: “. . . on such issues party divisions are forgotten, and members give chase at the mere scent of injustice like greyhounds after a hare."

10 A. de Tocqueville, Democracy in America, Vol. III, London 1838, pp. 84 ff.

11 The American Commonwealth, Chap. LXXXIV.

1,2 Aristotle seems to have had the same thing in mind when he said that democracy is characterized by two features, namely, by the rule of the majority and by liberty, although he does not state the relation between the two. (Politics, Bk. 5, chap. IX.) 
intolerance than minorities. However, when recently the present writer attempted to analyze the workings of what has proved to be the basis of such a successful synthesis of liberty and authority in our constitutional government, the Executive Secretary of the Proportional Representation Society exclaimed that this was a "philosophy of unity through compulsion. . . strangely akin to totalitarianism." 13 " There is no need to discuss such nonsense in any further detail. One hundred and fifty years of American history give the reply. So do the developments in most of the countries which have been unfortunate enough to adopt P. R.!

So much in regard to the system of voting which the proponents of P. R. reject, without making any effort to understand it. So far as their own alternative is concerned, it is none too easy to explain it, in particular so far as their favorite brand, the Hare system, is concerned. As Walter Bagehot put it: "No common person readily apprehends all the details in which, with loving care, he (Thomas Hare) has embodied it. . . . I have heard a man say: 'He could never remember it two days running.'" 14 To be sure, the advocates of P. R. have found a way of turning such difficulties into an asset. All over the country they are organized into rather esoteric little groups, and such groups always need their mysteries to distinguish the initiated from the rest. The intricacies of the Hare system serve this purpose very well indeed; apparently there are people who, after they have mastered the secrets of the vote and of the count, seem to feel that their time was wasted unless they could contrive to spend the rest of their lives in advocating what they had learned. As a result, as the Michigan Supreme Court ${ }^{45}$ noted when, in a memorable decision, it held P. R. unconstitutional, advocates of P. R. find it easy to combine the propaganda for P. R. with its explanation. And these very intricacies of the Hare system of P.R. made it possible to combine charm with both explanation and propagation when at a recent convention of the National Municipal League (with which the Proportional Representa1941.

13 George H. Hallett, Jr., "Letter to the Editor," New York Times, August 7,

14 Walter Bagehot, The English Constitution, ed. The World's Classics, p. 132. 15 Wattles v. Upjohn, September 30, 1920. 
tion League is now united, in spite of the misgivings of some of the most experienced fighters for municipal reform) the stage was taken by students from a fashionable girls' college, whose graceful movements were to explain the workings of the Hare system of P.R. Such charm cannot be reproduced on the printed page. Nor is it necessary to study the finer points of the matter. Again Walter Bagehot placed the emphasis where it belongs when he said that "the difficulty. . . is fundamental, and wholly independent of detail."16 For that reason, let us confine ourselves to the explanation and analysis of the bare essentials which underlie the Hare system as well as the three hundred odd other systems of P.R.

When we speak of Proportional Representation, the question arises, of course: Representation of what and in proportion to what? If under our current system of voting we speak of representation we mean that the candidate whom we elect is to represent not only his voters, and not only his local district, but in a fundamental sense the whole nation. ${ }^{17}$ Advocates of P.R. do not think of the nation as a whole. All they have in mind are the many different parts that compose it. Representation is sought for these parts, and proportionality means that these parts divide the seats in a legislative body among themselves in as close a proportion to their share in the total vote as can be attained. For example, if the House of Representatives contains 435 members, the most logical application of the principle of P.R. would demand that we divide the total number of votes cast into 435 , and give to each group of candidates as many seats as they have obtained the quota. For example, if $43,500,000$ votes are cast, a group which obtains 100,000 votes obtains one representative, and a group which polls 300,000 votes secures three seats, and so on. The proponents of P.R. assume that such a division of seats is but natural, and that, in fact, it is required in the name of justice. It provides, they continue, true and real representation. By presenting this line of argument they imply, of course, that such good political scientists as

16 Bagehot, op. cit., p. 132.

17 The problems of representation cannot be discussed here in detail. The author agrees with the thorough and comprehensive discussion which Professor C. J. Friedrich has given (Introduction to Democracy or Anarchy? pp. xxi-xxiv, and Constitutional Government and Democracy. Boston 1941, pp. 255 ff. 
were the Founding Fathers did not know what they were talking about when they were protesting against "taxation without representation," and then used the plurality system when they secured the representation they wanted. Further, the proponents of P.R. take for granted what they are supposed to prove. Is it really the purpose of elections to reflect "in true mathematical proportion" all that divides us, or is not their purpose to discover-and to strengthen-that which unites us? The answer has been clearly formulated by President Gideonse of Brooklyn College: "An election should not be a mere census of the voters' ideas and prejudices. It is a device through which the community registers from time to time such consensus as is reflected in the selection of 'representative' individuals and convictions." 18 As mentioned above, the majority system tends to create such consensus. P.R. neglects this task, and ultimately it accomplishes the opposite. It invites any and all groups in the community to elect their own men with their own votes-without any regard for what the rest of the people may think. The Cincinnati Enquirer gave a rather telling illustration of the implications of this tendency when it wrote: "It is clearly apparent that if there were 20,000 Hindu voters in Cincinnati they could elect a representative of their race to Council just because he is a Hindu and without reference to other necessary qualifications." 19 Now it is, of course, true that if a community has such a minority within its walls, it must take care of its interests as well as of the interests of all others. The common good, when properly defined, is indeed "the good of each and all." However, when such minorities are encouraged to seek their own electoral success without caring for anyone else, they ignore the contribution which they have to make to the good of "all." If all minority groups do so, no majority is left which could act on behalf of the community, which goes to show how close the implications of P.R. come to the major tenets of anarchism. ${ }^{20}$

18 H. D. Gideonse in his preface to F. A. Hermens, Democracy and Proportional Representation, Public Policy Pamphlet No. 31, p. iii.

19 Front page editorial entitled "Proportional Representation," issue of June 4, 1939.

20 As J. Phillips Quincy put it: "The separation into classes is the danger from which we have most to fear. Mr. Hare's system, it seems to me, would tend to encourage this: an honest local representation reduces it to a minimum. Whenever we split into college cliques, foreigners' cliques, workingmen's cliques, and so on, we shall be apt to fill our legislatures with narrow, headstrong men, who feel secure of their places. They will be class-representatives, not representatives of the people. They will carry 
In countries like the United States, England, or Canada, the most significant of the dissolving effects of P.R. would be the destruction of the two-party system. Whoever follows the literature on political parties in this country is aware of the increasing realization of the benefits which we derive from our system of two parties. One party is clearly endowed with the responsibility for carrying on the government, and the other is responsible for that criticism and restraint which is necessary in order to remind our rulers that they are "tenants at will" and that they will have to give an account of their stewardship to the people. That P.R. would be inimical to the two-party system is one of the matters upon which the proponents of P.R: talked frankly in the beginning, and with regard to which they have now begun to replace frankness by dialectical dexterity. When Thomas Hare explained the system of P.R. which is known under his name, he said that as a result of its operation "Many more candidates will be everywhere put in nomination; minorities. . . (will) far exceed the entire number of minorities now existing, by the operation of numberless affinities and compulsions, which, in a state of liberation, will dissolve the present majorities." 21 As late as the 1939 Convention of the Proportional Representation League, held in conjunction with the Convention of the National Municipal League in Indianapolis, one of the

out, if they can, any class-policy to which they may be pledged, despite the bitter speeches which equally extreme class-delegates will have the privilege of making at them. But it is difficult to see how any policy could be fairly tried under such an arrangement. It is surely desirable that opinions honestly held by a majority of the people should be tested by experiments made under favorable conditions. Such conditions, however, could scarcely be secured in the "happy family" of legislative objectors which Mr. Hare would exhibit." (The Protection of Majoritics, pp. 18-19).

21 Thomas Hare, The Election of Representatives, Parliamentary and Municipal. 4th ed., London 1873, pp. xv and 26-7.

What is written in the leading American exposition of P. R. (C. G. Hoag and G. H. Hallett, Jr., Proportional Representation, New York 1926, pp. 116-17) can hardly be explained in a sense much different from the one so frankly stated by Hare. However, like other latter-day proponents of P. R. these two writers endeavor to take some of the onus of the tendency against the two-party system which is inherent in P. R. by claiming that the two-party system is doomed anyway. As they put it: "Whether we like it or not, the two-party system does not seem to be a permanent institution: it is crumbling everywhere." (op. cit., p. 114) When they continue that a number of modern developments "have made the two major parties in most places insufficient for the expression of the people's varied interests and wishes" they leave little doubt that they are themselves opposed to it. The prediction of an imminent crumbling of the two-party system does, of course, not square with actual developments. Minor parties were less in evidence in the Congressional elections of 1938 and the Presidential and Congressional elections of 1940 than they have been for generations. 
speakers delivered a vigorous indictment of American parties, comparing them in dangerous potentialities to the totalitarian groups headed by Hitler and Mussolini. Also, members of the minor parties (American Labor Party, Socialists, Communists, Progressives) who provide the bulk of the followers of P.R. in this country, may on occasion talk on the subject of the two-party system with something less than enthusiasm. ${ }^{22}$ But, to repeat it, such frankness is now unusual. Instead, the proponents of P.R. will say that if a party has a majority of the votes P.R. will give it a majority of the seats, and at the same time make sure that the minority gets its share also. "Majority Rule and Minority Representation" is the new slogan. How artificial it is, is evident not only from those arguments in favor of P.R. which are so cleverly directed against the very principle of the two-party system, but also from the most cursory glance at American party history. The demonstrated voting strength ${ }^{23}$ of the Greenback party, the Populists and the Progressive coalition of 1924, not to mention the Republican split of 1912, leaves no doubt that under any system of P.R. which deserves its name ${ }^{24}$ the American two-party system would long be a matter of the past.

22 For example, Mr. Maurice Blumlein, Chairman of the American Labor Party of Yonkers in a Letter to the Editor of the Yonkers Herald Statesman.

23 For some details see Democracy or Anarchy?, pp. 422-36.

24 The decisive point is the size of the P. R. constituencies. If a hundred members of a legislative body are to be elected, a vote of one per cent of the total should, according to the logic of P. R., elect a member. However, if the country is divided into ten constituencies which elect ten deputies each, approximately ten per cent of the vote will be required-ten times as much as in the first instance. Ireland has, at the present time, fifteen constituencies which elect only three deputies each. A party must poll approximately one-third of the total number of votes cast in order to be sure of a seat. Since under a plurality system one vote more than one-half of the total is always sufficient, and less may do if more than two candidates are in the running, a system of three-member constituencies is more similar to the plurality system than to P. R. However, if it is necessary to curtail the most characteristic feature of P. R.the proportionality between votes cast and seats obtained-so severely, why not go all the way and return to the majority system?

In this connection a point of a more general nature is to be made. Advocates of $P$. R. are welcome to any objection which they may have to make to the arguments of their opponents. It is, however, one of the elementary rules of scientific controversy that if ever the refutation of an objection has been undertaken upon the basis of concrete evidence, this objection should be repeated only if a concrete reply is made to the concrete points advanced. If this is not possible the point should be conceded! Time and again the proponents of P. R. have disregarded this vital part of the rules of the game. This applies in particular to Ireland (dealt with in Democracy or Anarchy?, pp. 311-25), to the party system in pre-1918 Germany (pp. 214-17), to the results of P. R. in 'Switzerland (pp. 333-9), and the Scandinavian countries (pp. 
If P.R. tends to destroy any two-party system that may exist, and if, for the same reason, it dispenses with the tendency to set up two "blocs" in countries which have more than two large parties, it follows that P.R. is anti-democratic. Only under a system of either two parties or two "blocs" can the people make a direct decision upon the major issues of the day, and upon the personnel of their government. If there are a number of parties, none of which has a majority, the government of the country will have to be carried on by whatever combination of parties can be formed after an election, without the people having any voice in the matter. In other words, instead of a popular democracy P.R. tends to create a parliamentary oligarchy. What develops is, as long as any government can be formed, a government by parties rather than a government by the people. Is this what the advocates of P.R. have in $\operatorname{mind}^{25}$ when they tell us that the application of their system of voting would give us "more democracy"?

One more fundamental aspect of majority rule must be discussed. The question has often been asked how democracy can prevent that the liberty which it is bound to give from being used for its own destruction. The answer, of course, is that democracy must take a chance. Unless the people are actually willing and able to support democracy, democracy cannot exist and in fact it makes no sense. The experience in such countries as the United States and England; which have stayed away from P.R., would seem to justify a considerable degree of optimism in this regard. The reason for the staying power of democratic institutions in these countries is evidently that the majority of the people can indeed be trusted. ${ }^{26}$ They want to lead their daily lives undisturbed, and somehow they are aware of the fact that under modern conditions democracy is the only form of government which provides them with an opportunity to do so. Both American and English his-

348-55). Constant hammering on the facts of the matter has at last succeeded in convincing some of the supporters of $P$. $R$. that they stand little to gain if they advertise as a proof of the beneficial results of P. R. the conditions in Belgium (pp. 301-11) and the Netherlands (pp. 339-48) where democratic institutions were repeafedly on the verge of a complete collapse. When will they take cognizance of the facts in $t^{1}=$ other cases mentioned above?

2,5 They seem to be aware of its nature. See Hoag and Hallett, op. cit., pp. 116-17.

26 On the "pre-political" requirements of democracy which are additional to those here mentioned, see Democracy or Anarchy? pp. 207-8. 
tory has shown that the common man is indeed behind any democratic government which works reasonably well. Their actions justify the opinion expressed so vigorously by Jefferson in his first inaugural address: "If there be any among us who would wish to dissolve this Union, or to change its republican form, let them stand undisturbed as monuments of the safety with which error of opinion may be tolerated, where reason is left free to combat it. I know, indeed, that some honest men fear that a republican government cannot be strong; that this government is not strong enough. ... I believe this, on the contrary, the strongest government on earth. I believe it is the only one where every man, at the call of the laws, would fly to the standard of the law, and would meet invasions of the public order as his own personal concern." 27

If the average man can be trusted, if the fact that he is in a majority is the reason why Jefferson's optimism has proved right, it remains nonetheless true that there will be a minority which is not worthy of our trust and which would establish its own rule of force whenever given a chance. In this connection the particular kind of minority that we have in mind is, of course, most carefully to be distinguished from legitimate religious, racial and social minorities; such minorities can be expected to contain in themselves the same cross section of all types and tempers that we find everywhere else. As demonstrated above, the members of such minority groups may, under a majority system, be expected to mix politically with members of other groups and thereby to lay a solid basis for political cooperation and general understanding. The kind of minority that we have in mind in this connection is different. It may be characterized by the word "radical," if by that we understand people who are willing to use violent means to accomplish their political purposes. The application of "violent means" implies the willingness to disregard other people's life, property and good name. So far as the leaders of a "radical" group are concerned, their motives may be idealistic in the sense that for them violence is means to an end, although the killing of someone innocent of any crime re-

27 Modern Eloquence, vol. xi, New York 1928, p. 49.

28 See Paul Mallon's comment on "Minorities," in his column of Sept. 3, 1942. 29 On the meaning of the term "radical" see Democracy or Anarchy?, pp. 21-2. 
mains a killing, regardless of the motive. These "idealists" will be joined by others, who like violence for its own sake. Criminologists know that in any country there exists, at any time, a certain percentage of people with criminal tendencies. The instruments of civil government are there to keep this minority in check. However, if conditions are favorable for the development of "radical" political movements, people with criminal tendencies will realize their chance. What society normally represses as vice then becomes virtue, and people who are potential criminals will take full advantage of the opportunities offered them. The problem which we face is, therefore, to quote again Josiah Phillips Quincy, "The Protection of Majorities." It is the cardinal problem of our time, although political science has, despite the study which such men as Mosca, Pareto, and Michels have made of it from a somewhat different angle, given it rather scant attention.

From the fact that the majority of the people is usually willing to fulfill the duties of an ordered society, it follows that any system of voting which requires the consent of a majority, or near majority, of a cross section of the electorate as a condition of political success, will effectively serve the purpose of keeping unruly minorities under control. It is no less obvious that a system of voting such as P.R., which opens the door to any minority group, makes it possible for a radical party first to establish itself as a factor in political life and then, if and when conditions are favorable, to disrupt from within the political life of a democracy to such an extent that in the end the majority of the people no longer have confidence in themselves and in the democratic government which corresponds so well to their temper. They may be persuaded that all they can do is to choose between two kinds of radical groups, and if a sufficient number of them do so they will play power into the hands of one of the radical groups without actually intending to do so: ${ }^{3 \sigma}$

If we now proceed to discuss some of the practical aspects of P.R. it is not with the intention of repeating details which have been set forth before. The only purpose is to clear up misunderstandings and to reject misrepresentations. An attempt will be made to deal with all

30 For some dètails see Democracy or Anarchy?. pp. 19-30, 
points raised although, of course, it cannot be helped that to those critics who had nothing to say there is nothing to reply.

The first country to show the disintegrating effects of P.R. on a large scale was Italy. The first P.R. election was held in 1919, and parliamentary government, to all practical intents and purposes, came to an end with Mussolini's "March on Rome" (made in a sleeping car, so far as "Il Duce" himself was concerned) on October 28, 1922. The major consequence of P.R. was to destroy the cooperation between the moderate parties which had accompanied every election held under the majority system. The result of such cooperation had been that every time when the elections were over there was a definite basis for the formation of a new government. That such arrangements were unnecessary, under P.R. was one of the main reasons why P.R. was adopted. Consequently, after the two P.R. elections there were a number of parties, none of which was strong enough to form a government itself, but several of which were able to prevent anybody else from forming a government. This they did. P.R. further allowed the Fascist and the Communist parties to elect a number of deputies, for whom there would have been hardly a chance under the majority system. Other factors, of course, played into the hands of the Fascists, who lost no opportunity to exploit existing difficulties and to add to them to the best of their abilities. Italian democratic institutions had become a pushover by the time Mussolini decided to strike.

Since no specific objection has been raised against the author's treatment of Italy, it suffices here only to emphasize one of the methodological aspects of the matter. Care has been taken not to use the word "cause" in describing the results of P.R. The proper term is "condition," ${ }_{11}$ and the implication is that certain developments which have other immediate causes become possible only because P. R. has repared the ground for them. Any country contains in itself at any time some "causes" that make for integration, and others that make for disintegration. The point is that P.R. places great obstacles in the way of the former, and gives encouragement to the latter. To put it differently, the body of society finds itself in the same position as the

31 As mentioned previously; see Social Research, May 1937, p. 246. 
human body. The latter will always be beset by bacteria, which it is certainly interesting and necessary to study. Bacteria, however, never have the field to themselves. There is the natural power of resistance in the body, which normally is strong enough to eliminate the destructive germ. On the other hand, if the strength of the body is undermined, in some way the carriers of infection may easily have their way. Similarly, when we study the development of modern dictatorship, we should not think either exclusively or primarily about the "bacilli"Mussolini, Hitler, Pilsudski, and the rest. Neither should we indulge in a Carlylean view of history by giving our attention almost exclusively to the personal history of such men, nor spend all our time searching for an ideological pedigree. It is much more important to study those conditions which made things so easy for these leaders whose "leadership" largely consisted in stepping forward and toppling over what was beginning to fall under its own weight. Among these conditions systems of voting are bound to take a place of great-sometimes decisive-importance. The reason is that methods of voting determine the constitution of parliaments and governments, the only tools which democracy has to express and defend itself. Destroy those tools, and the body of democracy is at the mercy of infections which it otherwise could have thrown off easily.

A study of the background of the collapse of democratic institutions means as much for the building of the future as it does for the understanding of the past. The two go inseparably together. Victory for the United Nations will mean the end of Fascism as well as of Naziism, and there is every reason to hope that a new attempt at democratic government will mean that we will not again be burdened with the disruptive results of P.R. There is, however, a tendency among the Italian exiles to think of the establishment of a republic. To be sure, the Italian Royal House did not shine during the period of Fascist rule. But neither did the democratic politicians who made the Fascist uprising possible, and this applies in particular to Prime Minister Facta, who should have been a vigorous defender of democracy, but whose indecision, as Profesor Salvemini has informed us, ${ }^{\mathbf{3 2}}$ is more responsible for Mussolini's final triumph than the hesitation of the King. Is it

32 G. Salvemini, The Fascist Dictatorship in Italy. New York 1927, pp. 111-13. 
not true, as a witty Frenchman said some time ago, that "La Monarchie constitutionelle est la meilleure des Républiques"? ("A constitutional monarchy is the best republic.") Walter Bagehot has brilliantly demonstrated how great is the integrating effect which a monarchy has as a mere symbol. ${ }^{33}$ No danger need result from it. It has been pointed out before that if, under a parliamentary system of government, the Head of the State ever undertakes a policy to which a pariiamentary majority objects, he can be easily, and without much formality, removed from his position. ${ }^{34}$ There must, of course, be a majority that is homogeneous enough to be able to take such action, but Italy has always had such majorities as long as she did not use P.R., and might expect to find them again under the majority system.

Turning to Germany, it may be useful to emphasize that in spite of all artificial restrictions the forces of democracy were on the march even under the empire. In the elections of 1912 the Socialists had obtained 110 seats in the Reichstag, which then had a total of 397 members; the left-wing Liberals had 42 seats, and the Catholic Center party 90 . To the strength of Center party must be added the votes of the Hanoverians, the Poles and the Alsatians (32 in all) who cooperated with it in about the same way (and for about the same reasons) in which in England the Irish Nationalists cooperated with the Liberals. For the time being these parties did not act together; the prestige of the Imperial government was then too great for them to start a concerted drive in the direction of parliamentary government. However, in 1917 these parties combined to pass the so-called "peace resolution," which asked for a peace without conquest and indemnities. They did not follow up this initiative with consistent action, but they finally cooperated to establish a democracy when in 1919 they formed the socalled Weimar coalition and adopted the Republican Constitution of Germany.

Such anti-democratic elements as there were in 1919 disappeared from the scene without much of an attempt at resistance. The Emperor and the princes fled, and the leadership of the east-Elbian nobility (the Junkers) was thoroughly discredited. Under a majority system the

33 English Constitution op. cit., pp. $30 \mathrm{ff}$.

34 Democracy or Anarchy?. pp. 285-7. 
Republic could have consolidated its hold upon the people without too much difficulty. After a fair reapportionment, which in December 1918 the then Social Democratic government could have adopted had it wanted to do so, the Social Democrats would in all elections have been in a position to bid for a majority of the Reichstag. This might have pushed Center party towards the Right; it would then have formed the rallying point of a bloc of Centrist and Rightist parties, whose political anchor would have been much closer to the Center than to the Right. It is hardly probable that the Social Democrats, Center party, and the left-wing Liberals, taken together, would ever have obtained much less than two-thirds of the total number of seats. ${ }^{35}$ It is evident that very little would have remained either for the old brand of opposition to democratic government (the Nationalists) or the new brand (Nazis and Communists). The political picture would have been further simplified by the fact that there would have been no national minority parties, the districts from which they came having been ceded by Germany under the terms of the Versailles Treaty. The general impression confirms, in a sense, the charge that the majority system is a "scrutin d'écrasement"- "a system of annihilation," but, of course, of an annihilation of the opponents of democracy, carried out with the peaceful weapons of democracy! ${ }^{36}$

Proportional Representation soon encouraged the growth of radical groups at the Left and at the Right, and split up the moderate groups in the Center. The Weimar Coalition lost its majority in the very first elections to the Reichstag (held in 1920), never to regain it. There was no substitute; all governments formed in the face of an increasing

35 This is clearly proven by the calculations made by Dr. Schauff and the present writer. (Democracy or Anarchy?, pp. $223 \mathrm{ff}$;; $257 \mathrm{ff}$.) The total territory of the Reich was divided into 400 constituencies of equal size, this being the number of members which the Reichstag would probably have counted had a majority system been used. There was no "gerrymandering" in this arrangement, which was carried out by a neutral expert. When the Socialist writer, Decker, who was in favor of P. R., made similar calculations, he arrived at a result which confirmed the conclusions drawn by Dr. Schauff and the author.

36 One critic has objected that whereas the present writer charges that P. R. encourages radical parties and discourages moderate parties, there were large moderate parties in Germany throughout the period of the Republic. There were indeed, but in the end they were reduced to about one-third of the strength of the Reichstag and totally unable to take any political initiative. This is quite different from the two-thirds majority which they could have expected under the majority system. 
splitting up of parties were more or less artificial and more or less weak. As Edgar Ansel Mowrer has put it: "Every democratic Reichstag after the National Assembly of 1919, was composed of from ten to fifteen parties and until the rise of the National-Socialists, no single one of them ever controlled more than thirty percent of the total. Obtaining a majority was like trying to assemble guinea pigs on an open lawnby the time three were collected one had wandered away. An election, under these circumstances, did unfortunately 'give a remarkably accurate picture of the mind of the nation.' (Republican Germany by Quigley and Clark.) This was putting it mildly. In Great Britain the advent of a third party upset the normal play of forces. In the American Congress a small group of Insurgents were able to influence legislation decisively. Imagine the condition in these countries, had there been not one, but half a dozen small groups, each with power to pull out of a coalition and hand over the ship of State to the enemy! What a field for bargains, mutual back scratching, indirect bribery! and general intrigue!" 37

The game was finally up when in the two elections of 1932 Nazis and Comunists combined obtained a majority. No democratic government could conceivably be formed. The Reichstag was no longer capable of positive action, and power drifted to the octogenarian President and the intriguers around him. When, on January 30, 1933, they had Hitler appointed Chancellor, they did so to put themselves into power, rather than him and his followers. However, the Socialist leader, LaSalle, was right when he said long before that time that one could lose his neck trying to be too clever in important matters. $U_{p}$ to that time, Hitler had shown little cleverness, but much singlemindedness and stubborn persistence. This brought him where he wanted to be, and within half a year the Nationalist conspirators were as efficiently liquidated as the Republicans against whom they had conspired. ${ }^{38}$

The great responsibility which P.R. has in the breakdown of the

37 Germany Puts the Clock Back. New York: William Morrow \& Co., 1933, p. 185.

38 The importance of these conspirators must not be over-rated. Such pocket-size Talleyrands and Machiavellis as Papen, Ribbentrop, and Hindenburg's son, Oskar, exist in all countries. Only when the political institutions to which they are opposed are about to collapse under their own weight can they have real influence. 
German Republic is dear enough, ${ }^{38 a}$ and there is little force in the arguments which proponents of P.R. have advanced to explain it away. ${ }^{39}$ This applies to the most recent point made by, the Executive Secretary of the P.R. League as much as to his earlier ones. This time Mr. Hallett attributes the success of the Nazis to the fact that Hitler's party, when after the elections of March 5, 1933 it had no majority, remedied this defect by expelling the Communist deputies from the Reichstag. The argument implies that, had the Communists not been expelled, the Republic would have been saved-which just about goes to make the Communists the last and most effective defenders of democratic liberty in Germany! This trend of reasoning ignores two things. First, there is the matter of chronology. The Nazis expelled the Communists after they had come to power, not before, and sub. sequent developments showed that they were quite impartial and determined to expel everybody else as well. They did not need a majority in order to do this. It was enough that they controlled the police and were able to arrest any member of the Reichstag, whether it was legal or not. After that, a sufficient number of the members could be relied upon to be effectively intimidated into doing their bidding. It is interesting that in adopting such tactics they only followed the pattern closely adhered to by the first two members of the totalitarian family. When the Russian Constituent Assembly met and the Bolshevists found that they were in a minority, they just sent a couple of sailors over who, when things did not go right for their party, simply closed the assembly. This parliament, incidentally, had been elected by P.R. The adherents of that system of voting continue to tell us that we need it because it will establish parliaments so deeply in the affections of the people that the advocates of violence would not be able to act against them. Yet, it would be hard to find any parliament in history which was brought to as inglorious an end as the Russian Constituent

38a. P. R. was not the only institutional factor which played a part in the breakdown of German democracy. As Professor Brecht put it: "Its (P.R.'s) atomizing influence on the democratic legislature was made doubly dangerous by the popular election of the president, incompatible with it because, with none of the small parties able to carry partisans to victory, such an election will almost necessarily lead to the choosing of a political outsider." (Social Research, September 1942, p. 411.)

39 For a discussion of these objections see Democracy or Anarchy?. pp. 285-92.

40 Camera dei Depufati, Discussioni, Legislatura xxvi, p. 10670. 
Assembly! What the Fascists did in Italy differed only in degree from the procedure adopted by the Communists. Mussolini had 34 followers in the Italian Chamber, which had a total of 535 members, when he assumed power on October 28, 1922. Yet, on a later occasion he declared: "The power we have and we hold." 40 The methods did not matter to him, nor would they to any other leader of a totalitarian party. They all would know how to intimidate any parliamentary majority in order to have their way. We can only conclude that whatever resistance is offered to the advocates of totalitarianism has to come before they take over power; afterwards it is too late.

This leads to the second point. What was the attitude of the German Communists towards democracy while there still was a democracy? It was one of scorn, contempt and sabotage. The Communists were opposed to any democratic government, and to any positive measure which such government might propose. So, of course, were the Nazis, and as a result the Nazis and the Communists voted the same way with monotonous regularity. This meant that in their fight against democracy in German parliaments the Nazis could always rely upon the votes of the Communists-which is a factor that contributed to their subsequent success. The German Republicans might have won a one-front war, but the two-front war against both the Nazis (including their Nationalist allies) and the Communists was too much.

In the case of Germany as in the case of Italy the explanation of the past is a guide to the future. The military victory of the United Nations will be accompanied by a collapse of the Nazi régine which can be expected to be as complete as the downfall of the monarchies in 1918. Our war aims include the establishment of democratic government wherever it has a chance. No one need fear the political influence of the Nazis after a German defeat; those of them who survive it will be in hiding. What is necessary is, of course, "the protection of majorities." The common man in Germany is the same as the common man in all other countries. All he needs is an effective defense against the violence of such minorities (both from the Left and from the Right), as some future disturbances might bring to the surface. The experience of the Anglo-Saxon countries demonstrates how effective a 
defense against such violence is provided by the plurality system. Why not give it a chance in Germany?

The effects of P.R. have by no means been confined to the axis countries. Of the United Nations the first one to offer armed resistance to Nazi aggression was Poland, and Poland is one of the nations that suffered most severely ${ }^{40 a}$ from the effects of P.R.

Like all other new Republics which came into existence in Europe at the end of the first World War, Poland adopted P.R. without even discussing it; in the field of political theory the victory of P.R. was, at that time, almost complete, although the older democracies, in particular England, steadfastly refused to give up the majority stystem. For the election of the Polish Constituent Assembly the so-called d'Hondt system of P.R. was used, which provides for a fixed numbet of seats in every constituency. ${ }^{41}$ These constituencies were comparatively small, which reduced the chances of small parties. Still, P.R. made possible the success of 12 Polish and 2 national minority parties, none of which secured as much as 30 per cent of the total membership of the national assembly. Ultimately there were 14 Polish and 8 national minority parties; during the entire period of the Republic (until May 1926, when Marshal Pilsudski established his dictatorship) no less than 80 parties sprouted up, though not all were in existence at the same time. ${ }^{42}$ Some of these parties would also have existed under a majority system, and Poland could not have expected to witness the development of a two-party system. Still, it suffices to compare the results of the elections held under the majority system before 1918 in the Polish parts of Imperial Germany with those held in the same provinces subsequently under P.R. in order to realize that much of the splitting up of Polish parties is due to P.R. Also, it is probable that under the majority principle a system of two blocs would have de-

$40 \mathrm{a}$. Widespread illiteracy is one of the reasons why the functioning of democratic gavernment was bound to encounter great difficulties in Poland anyway. Still P. R. greatly intensified those diffculties. Without it democracy might well have survived. (See Democracy or Anarchy?, pp. 355, 207-8.)

41 For some details on the electoral system in Poland see $\mathrm{K}$. Braunias, Das Parlamentarische Wahlrecht. Vol. I, Berlin 1932, pp. 435 ff. See also M. W. Graham, Jr., New Governments of Eastern Europe, New York 1927, pp. 467-9.

42 R. J. Buell, Poland: Key to Europe, New York 1939, p. 89. 
veloped, which in many ways would have functioned like a two-party system.

It is not surprising that the multiplicity and heterogeneity of parties as produced by P.R. made the formation of governments an almost impossible task. There were 16 cabinets during the period from November 18, 1918, to May 14, 1926, which gives an average duration of 5 months and 20 days. For one-half of this period cabinets were formed by civil servants, which indicates that it was impossible to establish a moral coalition of parties. The first such government had to be resorted to in 1920, which means that like Germany Poland had a "Republic without Republican" right from the start.

The attitude of the Polish parties during this time exhibited all the short-sighted selfishness which is known to the student of P.R. from a long list of other countries. At one time Mr. Thugutt, one of the leaders of the Radical Peasant group, declared in an open letter that the parliament "while not without a capacity for sacrifice in moments of crisis, was afflicted with a probably incurable impotence." He continued: "In Poland everybody desires to be in the opposition, but nobody is willing to take responsibility. Poland cannot prosper by criticism alone." ${ }^{43}$ So far as the period immediately before Pilsudski's coup d'etat is concerned, Machray says: "Many Poles, too, had by this time lost all faith in the Sejm (the parliament) - the Executive as well as the Legislative power; indeed, its general impotence, owing to party strife with all its extraordinary bitterness in Poland, was seen and known to all men. Added to its futility was the fact, which came to the surface now and again, that it was tainted with corruption, bribery, 'wrangling' of offices and posts in and under the administration and concession hunting." ${ }^{44}$ Pilsudski used even more vigorous language when he said that the Sejm was "a sterile, jabbering howling thing that engendered such boredom as made the very flies die of disgust;", it was comparable, he said, to "a locomotive drawing a pin." 45 For years, after he established his personal rule, Pilsudski nevertheless did not disband the Sejm. A contributor to the (London) Tablet

43 R. Machray, Poland 1914-31, New York, E. P. Dutton \& Co., 1932, p. 280. 44 Ibid., pp. 301-02.

45 Ibid., p. 359. 
gives the following reason for this course of action: "Pilsudski, wiser than Mussolini, did not abolish the elected assembly. . . . He calculated rightly that if the Sejm was allowed to go on with its party struggles in the public eye, it would lose any hold on the public affections, and so it did." 46 This was indeed the case, but it would be hard to find a parliament elected under the plurality system about which the same thing could have been said. Pilsudski neither in 1926 nor later held a majority in the Sejm. He failed in the elections of 1930 in spite of the strongest administrative pressure brought against the opposition; this included the arrest and, some say, the torture, of leading men of the oppositin in the fortress of Brest-Litovsk. Again he demonstrated that a dictator, once in power, will maintain himself whether he has a parliamentary majority or not. The Sejm was finally abolished in 1935, and the people did not seem to be unduly disturbed over its demise. They may have felt like R. L. Buell ${ }^{47}$ who said that Pilsudski's regime "probably prevented the growth of anarchy."

Some observers have held that in a country like Poland P.R., in spite of its admitted disadvantages, was necesary for the protection of the large percentage of national minorities, which has been calculated as high as 40 per cent of the total population. ${ }^{48}$ This argument figured largely in the discussions of the Paris peace conference, not only with regard to Poland. It is bound to play a large part again in the negotiations which will follow World War II. For this reason it is necessary to discuss it, no matter how briefly. In the case of Poland, of course, the question arises whether anything could have made the fate of the minorities much worse than it was anyway. Of the nearly two million Germans more than half had left the country, for the most part under compulsion of one sort or other. These Germans had at least a place where they could go, and to those who remained in Poland the Weimar Republic gave all the protection she could, in particular after Germany joined the League of Nations in 1926. For the Ukrainians and White Russians no such protection existed. So far as the large Jewish minority is concerned it should, however, be added in all fairness that it had

46 The Tablet, August 23, 1941, pp. 122-3.

47 Op. cit., p. 95.

48 Buell, op. cit., p. 237. 
to suffer more from the prejudices of a largely uneducated people than from measures taken by the government.

If we discuss the argument that P.R. is needed for the protection of national minorities, it must first be borne in mind that such minorities will benefit from P.R. only if they are scattered over a wide territory. If they are geographically concentrated, they are likely to benefit from the majority system, ${ }^{49}$ at any rate as long as they are not the victims of gerrymandering. ${ }^{50}$ If national minorities are scattered over a wide territory they will elect more deputies under P.R. than under a majority system, but in parliament they will still be a minority, and will be out-voted at every turn if the members of the majority group unite against them. Also, it must be borne in mind that P.R. encourages the Radicals both among the majority and the minorities, much to the detriment of the people on both sides who are willing to "live and let live," who always are likely to be in the majority, ${ }^{51}$-at any rate in the long run. In this connection it is important that under a majority system the voters belonging to a national minority group may use their votes in order to turn the scales against the one of the two leading candidates of the majority group who is less distinguished by a tolerant attitude than his rival. This further implies that the members of both the majority and of the minority groups are invited to mix right at the bottom of the political pyramid. Cooperation which takes place at this level is always more effective than cooperation among elected P.R. deputies in a legislative body, the reason being that if, as happens under P.R., the deputies of both the majority and of the minorities have been elected by members of their own group, without any regard for the existence of the others, they find it very hard indeed to cooperate in parliament. Let it be added that if the application of P.R. leads to

49 This was the case with the national minorities in pre-1918 Germany.

50 Gerrymandering is not at all impossible under P. R., and was openly practiced in Poland. For example, in purely Polish Cracow one deputy was elected to every 46,000 inhabitants; in Ukranian Krzemieniec one to every 98,000 (Braunias, op. cit., p. 437.

51 The same consideration applies to all other countries, including the United States. To quote again from a recent column of Paul Mallon, in which he drew some conclusions from the mail which he had received after discussing some of the current antagonisms in this country: "Those who really hate are minorities of the minorities on both sides." (South Bend Tribune. September 3, 1942.) 
the breakdown of democratic government, the minorities will lose those civic rights which even an inefficient democracy will try to enforce. In Italy, for example, the treatment of the Slav and German minorities was generous under the parliamentary regime, only to become abominable as soon as Mussolini took over.

For these reasons minority rights should be safe-guarded in a more direct way than by adopting P.R. As Pope Pius XII put it: "Within the limits of a new order founded on moral principles, there is no place for open or occult oppression of the cultural and linguistic characteristics of national minorities, for the hindrance or restoration of their economic resources, for the limitation or abolition of their natural fertility." 52 This sentence clearly enunciates the essential rights of minorities, and these rights should be secured by international agreement, which ought to be supervised by impartial authorities. The basic arguments which have been advanced against such a solution are derived from the complaint that the sovereignty of the country concerned would be impaired. The term sovereignty, however, is a product of absolutism; it was used to rationalize the absolute prince's demand to be free from moral obligations both with regard to other countries and to his own subjects. Those who believe in democratic government either should not use the term at all, or modify it severely. In a number of European states the superstition of absolute sovereignty has been overcome by concordats with the Holy See, the purpose of which, of course, is the protection of the religious rights of the Catholics in the countries concerned. No nation ever lost its independence by virtue of a concordat, and none will do so on account of an international guarantee of the rights of its minorities, it being understood that such guarantees should be mutual and universal. Also, we must bear in mind that, as Pope Pius XII puts it: "The more conscientiously the government of the State respects the rights of minorities, the more confidently and the more effectively can it demand from its subjects a loyal fulfilment of those civil obligations which are common to all citizens." 53

52 "Christmas Message of Pope Pius XII," International Conciliation, February, 1942, p. 89.

53 lbid. 
Like Poland, Czechoslovakia had a great minorities problem, and in her case it was also at first assumed that the adoption of P.R. would settle the issue. Of course, it did not; there were complaints on the part of the Ruthenians, Hungarians and Poles, as well as of the Germans, and the relations between the Czechs and Slovaks were often marred by friction. In these antagonisms there was perhaps much that was inevitable. Since, for example, until 1918 the Czechs had been playing second fiddle to the Germans, many of the Czechs thought it was only right that afterwards the Germans should play second fiddle to them. In such cases it takes some time before a proper relationship is established upon the basis of mutual toleration and respect, although this is the aim towards which all official policy should be directed and certainly the only one that should be encouraged from abroad. ${ }^{54}$ During the last years before Munich, however, progress was made; the Czechs were willing to admit mistakes ${ }^{55}$ and work for their correction. Also, Czechoslovakia remained-in spite of some features to be discussed immediately-enough of a democracy to provide more of a guarantee of individual liberties than did any other state in central or eastern Europe, with the result that minorities fared better than practically anywhere else.

P.R. did little to assist in the solution of the minorities problem. It gave encouragement to the radical minorities both among the Czechs and the Germans. ${ }^{56}$ To be sure, in the 1935 elections Konrad Hen-

54 In a country with such a mixture of nationalities as Czechoslovakia, a new Switzerland has been advocated as the only ultimate solution. It presupposes, however, that no nationality is in a position to de-nationalize the other, and in Switzerland this is guaranteed by the fact that the various nationalities, in their respective "cantons," are in full control of local administration, including the school system.

55 "As Dr. Benes put it: "I do not hesitate to say that in these matters (referring to economic problems) mistakes have been made which must not be repeated, such as, for instance, that contractors and workmen have been called from Czech or CzechGerman districts into German districts where unemployment prevails." (E. Benes, The Problems of Czechoslovahia, Prague 1936, pp. 18-19). For a brief description of such problems see R. Freund, $W$ atch Czechoslovakia, New York 1937, pp. 55-60. For the agreement of February 1927, by which a solution of the most urgent problems was attempted, see ibid., p. 65.

56 As Dr. Benes expressed it: "I am glad to state that in general the German officials and employees and the German soldiers fulfil their duties to the Republic very satisfactorily, that the greater part of the German population are loyal to it as their fatherland, and thus the German parties adhering to the Government fulfil their duties to the state in self-sacrificing fashion. It needs only a fraction of the population, however, to come forward with alluring if impractical watchwords to provoke distrust on the other side." (Ibid., pp. 19-20.) 
lein's party obtained a majority of all the German votes. This party served Hitler's aims perfectly, although it contained many a member who would have resented being called Nazi. However, it is one thing to take votes away from a party when it is as centralized, as impersonal and as unpopular as all parties (the old German as well as the Czech parties) were under P.R., and another to deprive individual deputies of their seats in single-member constituencies. American attempts at "purges" have shown us how strong the position of an incumbent is in such a case. Also, the application of the "leadership principle" within the Sudeten German party was greatly facilitated by the power which the system of voting gave to the central party committees.

Czechoslovak political life is so definitely characterized by the typical effects of P.R. that their adequate description would require a volume. ${ }^{57}$ A system of "rigid lists" 58 prevailed; party committees would present lists of candidates for one of which the voter had to vote without being able to make any changes. Individual members of parliament were almost slaves of their party leaders. Before they were nominated they had to sign a declaration that if they left their party they would resign their seats. According to the jurisdiction of the electoral court, whose members were appointed by parliament (which means by the party leaders) exclusion of a deputy by his party would practically deprive him of his seat. As a result, party discipline was even more severe than in Republican Germany, where it was already too severe to be compatible with the requirements of party democracy and party vitality. There were many charges of corruption, and public opinion forced parliament in 1924 to pass a law which was to prevent the close association between deputies and private economic interests. The law was practically not enforced.

The splitting up of parties was considerable from the beginning, and was later intensified. When this became apparent, the electoral law

57 For some details see Braunias, op. cit., pp. $567 \mathrm{ff}$. For a remarkably frank analysis of Czech political parties as they developed under P. R. see J. Chmelar, Political Parties in Czechoslovakia, Prague, 1936. See also C. Pergler in Notre Dame Lawyer, March 1942, pp. 282-3.

58 Between the systems of rigid lists and the Hare system of P. R. the differences would be minor if ever the attempt were made to apply the Hare system in large constituencies, as should be done if full proportionality is the aim. (See Democracy or Anarchy?, pp. 56-7.) 
was modified; a party was to obtain seats on the national list only if it obtained seats in the local constituencies. The votes for which the small parties could not obtain seats of their own were not simply disregarded, but-a unique feature-attributed to the large parties. Also, the city of Prague was artificially divided into two constituencies in order to make the success of small parties more difficult. Later some of the small parties learned how to circumvent these provisions by technically cooperating with one another or with larger parties; in parliament, however, they formed groups of their own. Thus while in 1929 only 16 party lists secured seats, they went actually to 24 different parties.

It goes without saying that this multiplication of parties made the formation of governments ${ }^{59}$ a difficult task. A number of coalitions followed one another, and several cabinets of civil servants became necessary. Eventually the coalitions proved unable to maintain the normal process of legislation, and "acting under sweeping enabling laws, the government ruled more and more by decrees under the ultimate control of the parliament." 60 It is obvious, however, that no matter how lumbering the operation of Czech democracy had become, it still worked better than the one in Poland. National sentiment was strong in Czechoslovakia; it was embodied in such non-political organizations as the Sokols (athletic groups) which did much to unite what the P.R. parties had artificially separated. Also, there was the almost legendary figure of the first president, Masaryk, who patiently brought the parties together again and again and often succeeded in reconciling the unreconcilables. His successor, Benes, was involved in more controversy than Masaryk, but was still a much more powerful factor than the head of the state normally is under the parliamentary system.

Still during the last years of the Republic symptoms of crisis were abundant, and it was deemed necessary to take some of the steps which Professor Löwenstein has summarized under the heading of "Militant Democracy." 61 In 1933 a law was passed empowering the government

59 The various cabinets have been discussed by M. W. Graham, in: Czechoslovalia, Tweniy Years of Independence, edited by R. G. Kerner, Berkeley 1940, pp. $148 \mathrm{ff}$. See also Chmelar, op. cit.

60 K. Löwenstein, "Militant Democracy and Fundamental Rights," American Political Science Review, August 1937, p. 641.

61 Ibid. 
to suspend and dissolve any group which, in the government's opinion, was "apt to endanger the constitutional unity, the integrity, the republican-democratic form of the state or the safety of the Czechoslovakian Republic." 62 The law at the same time enabled the government to restrict the freedom of press, speech and assembly. The essential feature was, of course, that such sweeping powers were given to the executive, which in their use could not help but be influenced by con. siderations of partisan policy. This, of course, is not what we underrtand by democracy in Anglo-Saxon countries, and the then Czech Premier, Dr. Milan Hodza, admitted as much in an interview given to the Communist newspaper, Izvestia, in which he said: "For the time being I see in Europe three types of democracy: the liberal Fiench democracy, the chief characteristic of which is liberalistic freedom; further, the traditional English democracy which by way of an individualistic citizen tends toward a rigid voluntary discipline. In Czechoslovakia there has developed a third type, a coordinated democracy." 63

Commenting upon this, Dr. Pergler writes: "Just what Dr. Hodza means by a 'coordinated democracy' he never explained. Certainly he must differentiate it from English voluntary self-discipline, and if he does, then he, of course, means an imposed discipline. Who shall impose it?" The reply is, of course, the government, which again means that one group of parties is given somewhat arbitrary powers over other parties. Also, it is doubtful whether this policy ${ }^{64}$ was really successful. The Czech Fascist and Communist parties were allowed to exist, although both of them came within the meaning of the law. The original German Nazi parties had been dissolved by an administrative act before the law was enacted. When later Henlein founded his Sudeten-German party he was careful to comply with the provisions of the law, and yet he proved to be an even more efficient tool of Hitler's policies than the original Nazi parties had been. On the other hand there is little doubt that the legitimate aims which Czech "coordinated democracy" sought by means at variance with democratic traditions

62 Ibid., p. 642.

63 "Modern Dictatorships-Will They Survive?" Reprinted from World Affairs. December 1936, p. 5.

64 It is, however, viewed favorably by Dr. Löwensein, op. cit. 
could have been accomplished without discrimination against anybody by the majority system. There would have been no chance for the Czech Fascists, only a slight chance for the Communists (who were not divided according to nationalities), no chance at all for the original Nazi parties, and, for the reasons mentioned above, Henlein might have found the going rather hard if with his Sudeten German party he had tried to dislodge the incumbent German deputies from single-member constituencies in which most of them would have been firmly entrenched. Also, there would have been less disintegration so far as the moderate Czech parties are concerned; for such groups as the "Small Traders Party" there is simply no place under a majority system. Therefore, the position of the Czech government would have been stronger and more secure-without any law giving it discretionary powers against anyone.

The question arises whether the results of "coordinated democracy" did not have something to do with the surrender at Munich. To the present writer it has always seemed that the right of self-determination has much more in its favor than its critics admit, but it is not necessary to go into that matter here. To allow the Sudeten Germans to join the Austrian or the German Republic was one thing; to throw them into the arms of Hitler was another. When Hitler took the Sudeten districts he did not do so in order to give self-determination to their inhabitants (who immediately passed under the rule of the Gestapo), but in order to take it away from the Czechs and, as soon as possible, from just about everybody else. It is incomprehensible why the Czech government did not see this. To be sure, they were under strong pressure on the part of France and England, but then, why did they yield to this pressure? In fact why did they allow themselves to be maneuvered into a difficult tactical position by admitting Lord Runciman? If Dr. Gallup had at that time been operating an Institute of Public Opinion in Czechosiovakia, he would have found a tremendous majority in favor of rejecting Hitler's demands. The mood of the people left no doubt about this. However, throughout the negotiations the government, fortified by the powers of "coordinated democracy," severely restricted the freedom of the press and of assembly. Ultimately they issued the order of mobilization and placed the country 
under martial law. The people thought that this was done to prepare for military resistance, whereas the actual purpose was to make surrender easier. Just how much the results of "coordinated democracy" had to do with this is, of course, irapossible to tell. But there will probably be agreement on the point that in such a situation the will of the people should prevail rather than that of the government, and that the people should have the fullest opportunity to express their will.

Considerations of space make it impossible to deal with Finland, ${ }^{65}$ which also extensively used the instrumentalities of "militant democracy" in order to defend herself against evils which were largely the result of P.R. Nor can the Baltic States be discussed at this time, full as they are of lessons on the effects of P.R.

But is it necessary to give any additional details in order to show that at the end of this war the peoples of Europe would risk losing everything that both we and they are now fighting for if they should once more entrust the formation of their legislative bodies to P.R.? It is indeed hard to regard P.R. as anything but an excellent device to destroy at the polling booth that liberty for which men have to fight on the field of battle.

65 To quote a passage from Dr. Braunias (op. cil., pp. 142-3), which concerns principally the conditions prevailing during the 1920s: "Thus all governments were governments by coalition which contained the germ of decomposition within themselves. At times also governments of civil servants were formed (for example, the one headed by $M$. Cajander) although minority governments were more frequent. No government existed for more than a year, and the average lifespan was 10 months."-On measures of "militant democracy" see Löwenstein, op cil., pp. 638-9. 